\title{
'ON ELECTION DAY THE HUSBAND TIED HIS WIFE TO A TABLE LEG TO STOP HER FROM VOTING' \\ POLITICAL NARRATIVES, GENDER AND ARCHIVED HERITAGE IN FINLAND
}

\section{Pauliina Latvala}

\begin{abstract}
This paper seeks to explore the relationship between gender and political narratives by drawing on autobiographical memoirs generated by way of a collection project called Politics and Power Games, which was organised by the Folklore Archives of the Finnish Literature Society in 2006-2007. The materials stored in the memory institution with a long history of collecting cultural heritage open up a terrain for experiences of political culture and traces of gendered political heritage as occurring in ordinary people's minds and narratives. By highlighting experiences of gender-based political culture, the article aims to show the importance of collecting and archiving political narratives as part of history culture and heritage. When writing to an archive, narrators participate in a dialogue not only between the present and the past but also between the personal and the public sphere.
\end{abstract}

Keywords: archive collections, autobiographical memoirs, cultural heritage, gender, history culture, oral history, political culture, political narratives

\section{INTRODUCTION}

Although masculine voices have traditionally predominated in the political arena, perceptions may nonetheless start to change upon closer examination of ordinary citizens' political memories. In Marianne Liljeström's terms (2004a; $2004 \mathrm{~b}$ ), politically hued life experiences can be situated in the contexts of gendered experiences. In this article, I aim to describe the narrativisation - understood as the way memories are turned into written stories - of day-to-day political culture, by examining gender representations in political narratives (for more on the concept of narrativisation, see Benton \& Cecil 2010: 18; Schudson 1995: 348). The narrativisation of politics as part of the act of memorising is always bound to various contexts: the context of recollected time and its political culture, the context of the dialogue and the imagined receiver of the text, and 
in this particular case the Folklore Archives as a national memory institution, researchers even in the future, and the context of the writer's personal life history. Furthermore, the context of political and cultural history with the myth of strong and politically active Finnish woman must be taken into consideration.

Finland was the third nation-state to grant women full political citizenship. Women from different social classes were also elected to the first parliament in 1907. Unlike in England and the United States, there was no widespread suffragette movement in Finland; instead, the rural populations and members of the recently urbanised working class simply made their right to vote more vocal (Sulkunen \& Markkola 2009: 9; see also Sulkunen 1991: 70-73).

The abovementioned circumstances have all been combined in the creation of the enduring myth of the strong-willed Finnish woman. This is a notion that harks back not only to women's participation in hard toil alongside men, but also to their early right to vote in state elections and their active role in politics (Markkola 2002: 75). These circumstances have often been positively narrativised in our culture and viewed as proof of gender equality.

It is possible, however, to examine the background to women's early political rights from a slightly different angle. For example, Jaana Kuusipalo's dissertation (2011) on gendered political representation shows that the political rights accorded to women were not based on a belief in equality but rather in difference; in other words, women as citizens or even as politicians were seen as fundamentally different from their male counterparts. Modern citizenship with its social and political dimensions was seen as gendered, which therefore justified women's place in politics as 'mother citizens', those who would champion the causes of other women, children and the disadvantaged. This mindset brought relief to the men who needed to focus their attention on matters of state. Since the $1960 \mathrm{~s}$, these perceptions have been questioned thanks to the women's movement, but the path of women to higher offices within the political system did not take place overnight (Kuusipalo 2011).

Although women achieved equal status to men even in the highest echelons of political power already in the year 2000, with the election of a female president, I have not come across any research on how citizens from different political backgrounds feel about women's equality. My own research data does not provide an adequate answer to this question either. Nonetheless, the material allows a voice to those who still question gender equality.

The source materials of my research consist of the responses sent to one of the archive's national collection campaigns Politics and Power Games: Oral History on Social Activity in Finland. In the international context, as Ronald J. Grele (2007) stresses, oral history has been seen as a "conversational narrative created by the interaction of the interviewer and interviewee". Researchers in 
Finland, however, often use the same term to refer to written archived collection material dedicated to a general theme. ${ }^{2}$

Gender-based memorising can be seen as a dynamic counterforce to historiography, which is often one-sided and biased (see also Heimo 2010: 18). Putting personal experiences into words enriches the image of the past and highlights how individuals structure the significance of memory and narration, and how the past is positioned vis-à-vis the mirror of the present. ${ }^{3}$ Before examining the gender representations and narrativisation, I will first outline some more general arguments about the research material and contextualise the collection of political narratives as archived heritage.

\section{COLLECTING PERSONAL EXPERIENCES ON POLITICAL PAST}

The Politics and Power Games collection campaign aimed to gather memories, narratives and experiences of political culture at the grassroots level. The campaign was launched by the Finnish Literature Society Folklore Archives in 2006-2007, as part of the national celebrations of the 90th anniversary of Finland's independence. The year 2006 also marked the centenary of women's full political rights in Finland. The co-organisers of the collection project were the Union for Rural Culture and Education, Finland 90 Years, the Coalition of Finnish Women's Associations, the Women's Working Group for Rural Development and the Finnish Social Science Data Archive. ${ }^{4}$ The ideological background of one of the co-organisers, the Union for Rural Culture and Education, can be traced to the Centre Party. There were 203 respondents, who provided a total of 2,333 pages of written text for the collection project. Women submitted 128 responses, whereas men submitted 75 . The youngest respondent was born in 1986, the oldest in 1914. Most of the writers were born between the 1920s and 1940s. The political orientations of the respondents can be discerned, though at varying intensities; yet it must be mentioned that not all respondents overtly spell out their present political loyalties. ${ }^{5}$ As they describe their own experiences of political socialisation, the narrators underline the shifts that have taken place in their political thought.

Within the questionnaire framework, Finns were able to write freely about the following seven themes: Politics in the family and home region, Possibilities for social or political action during different periods, Voting and candidates, Gender and power, Youth and politics, Political parties, Power and challenges to politics, and Politics, regionalism and civil society. The samples from the archive materials open up perspectives onto gendered views and experiences, especially in the rural communities in the 1900s, right up to the 1960s. For 
example, the Martha Organisation and their local associations, which have sought to improve the welfare of homes and families especially in rural areas for over one hundred years in Finland, figured prominently in the responses. The Marthas are often regarded as centre-right on the political spectrum, though the organisation presents itself as neutral.

We can then ask how the role of the Finnish Literature Society as the organiser of the campaign has shaped the contents of the collection? There is no clear-cut answer to this question. Nonetheless, Ulla-Maija Peltonen, when researching the memories of the Civil War of 1918, noted that narrative materials on the same theme differed to some extent, depending on the archive to which they were sent. For instance, one respondent who had neglected to send any accounts of negative deeds or violence perpetrated by the Reds to the Labour Archives, did choose to share such information with the Folklore Archives of the Finnish Literature Society (see Peltonen 1996: 133). We could thus assume that the writer felt a greater sense of freedom when responding to the politically neutral Folklore Archive's collection campaign. Nonetheless, there is no information as to whether the archive respondents consider the institution established in 1831 politically hued and if indeed they do, then to what degree. Many of the respondents who took part in this particular collection campaign had already participated in collection campaigns in the past. These respondents may have also had some familiarity with the Society's history, which is clearly bound up with nationalist ideology, and would have thus already had an inkling of the reception of their writings on the past. It must be noted, however, that no attempts have been made to survey perceptions about the archives, even among the networks of regular respondents.

Although the archives provide writers with instructions for each collection campaign, the respondents can ignore them if they like. They always have the freedom to write exactly what they find meaningful to pass on. For example, personal stories about the political atmosphere make up a part of the textual expressions of the past, present and future political culture, although the future was not included in the list of themes in the brochure. Each person involved in the act of recollection has to feel that the perspectives and memories that he or she has picked up and incorporated into his or her own stories are worth telling, saving and sharing. Despite their gaps and inaccuracies, their occasionally fabricated utterances, and their kinship closer to fiction than to historical documents, these texts have a unique value. Voluntary recollection does not need to follow any rules; there is no obligation to remember everything as it was (if such a reality ever existed in the first place). The act of creating images of the past and ascribing meanings to them involves assuming power 
and defending one's viewpoints, and thus controlling the images of the past. The writers know that their memories enter the public realm once they have sent the texts to the researcher or the archive. Although the writing process itself may be private and the writer may set restrictions to use, many writers no doubt choose to leave certain opinions, events or things unwritten because of the public nature of the archive text (cf. Miettunen 2009).

\section{NARRATION OF POLITICAL PRACTICES AND EMOTIONS AS HERITAGE FROM BELOW}

Each writer highlights the local individuals and events that they find important for their memories. The narratives generated through the campaign elucidate the dynamics within the families and local communities as part of the wider political culture. One of the most compelling questions in the narrativisation of politics concerns the kind of politically oriented memories that Finns value as their own political heritage. ${ }^{6}$ Before we can address this question, we must first establish the concept of 'political narrative'.

It may be understood and used in many ways, depending on the researcher and field of study. Molly Andrews, a sociologist who has conducted research projects in Britain, the United States, East Germany and South Africa, highlights the aspects of political change and power in political narratives (Andrews 2007). She notes that "those stories may not necessarily be overtly about politics: these stories often reveal how individuals position themselves within the communities that they live..." (Andrews 2012). In political narratives written by Finns, the political practices of the community, such as excluding/including, or attitudes regarding women's political activities, are also essential. In addition, the narratives consist of emotions about everyday political atmosphere (even without political change) and many genres of folklore representing conflicting values - past and present - in the community. This is why I have chosen to examine the traces of emotional memory in political narratives.

Laurajane Smith (2006: 44-45) has explored new ways of understanding the nature of heritage as experience and a cultural process. Here she follows David Lowenthal (1985), who has stressed that heritage is a way of engaging with a sense of history. In her book, Uses of Heritage, Smith explains how she came to understand this while conducting fieldwork among indigenous women in Australia: instead of simply focusing on the places that were important to the women as heritage sites, oral history emerged as a central feature of the project. Smith (2006: 46) writes: 
What was interesting for us was that for the Waanyi women these oral histories were perceived to be as much their heritage as the sites we had intended to record. [---] passing on the oral histories and traditions was, for the women, an act of heritage management, as this heritage was being recorded and preserved as recordings.

The act of heritage management resonates with the concept of vernacular authority, which operates outside formal discourses and institutions (Howard 2013: 81; see Heimo 2014). If we look more closely at political narratives on the private level, we notice that transmitting the interpretations and notions of the local and family pasts usually makes history more relevant, and that version of the past is the one that people find most compelling (e.g., Kalela 2012; 2013). The relationship to history, to the reality of the former generations and to the magnitude of experiences is transmitted on a daily basis through language and narrative genres. In this process, the archive respondents enlarge the image of the past by making space for the forgotten parts of the past.

As researchers in critical heritage studies have pointed out, the division between tangible and intangible is not relevant after all. They are not opposites (Smith \& Waterton 2009: 291-292). If we took this idea even further, we could say that heritage does not exist but is rather created alongside the choices that people and institutions make when they present the valuable aspects of their culture (see Bendix 2009: 255; Olsson forthcoming). This is true in the case of archived heritage (see Edmonson 2002; cf. Olsson forthcoming): tangible collections saved for future generations include descriptions of intangible culture and everyday practices, the use and meaning of vernacular language, folklore genres, etc. ${ }^{7}$ Most important are the kinds of processes that heritage generates in different contexts by different agents; in this particular case, the context of archive collection campaigns by those willing to share their memories and experiences.

\section{MASCULINE AND FEMININE VOICES}

The centenary of women's full political rights may have encouraged the writers to focus on the theme of Politics and Gender, or, at the very least, views and interpretations associated with it. Nonetheless, all respondents - men and women alike - touched upon the theme at least on a general level. Although there was no particular emphasis on political pressure in the brochure explaining the aims of the collection, it did feature questions about ideas and expectations related 
to gender and politics. Here are a few examples: What is the significance of a female president in Finland?; In your opinion how well has equality been realised in Finnish politics? Nonetheless, the last question on the theme - How have politically active women been viewed in your home region in previous decades? - did serve to elicit both collective stories and personal experiences.

Since the 1980s, the study of women's oral history has spurred international discussion, thus giving voice to female narrators, women's culture and history. Although there is no archive dedicated solely to women's history in Finland, the Finnish Literature Society is known for having a predominantly female network of respondents. Women from rural areas, especially in previous decades, have also actively contributed their recollections of the past to the National Archives. By examining gender conflicts surfacing amidst other themes recollected thanks to the National Archive's questionnaire The Status of Women (Naisen asema), ethnologist Pia Olsson (2011; forthcoming) challenges the myth of the strong Finnish woman. The collection campaign in question was extremely popular among women; in fact, there were about 1,000 responses in total. According to Olsson, the older generations represent the most active proportion of the respondents. ${ }^{8}$ It must be said, however, that analogous collection projects specifically aimed at male respondents have yet to be organised. Nonetheless, Olsson reminds us that the gender distribution of respondents has to be examined in relation to the questionnaires. For example, many of the questionnaires sent out by the National Board of Antiquities, especially in the early years, have been dedicated to questions particularly related to 'masculine' themes. Needless to say, politics can be counted among them.

The more visible role of men in political life in the past may partly explain why female contributors to unofficial history have often chosen to send their written recollections to archives that are openly aligned with a given political ideology - indeed, the Labour Archives serves as one example. Interestingly, however, The Politics and Power Games collection campaign succeeded in reaching more female than male respondents. Female interest in the project may have been stirred thanks to the way that political discussions had begun to permeate the (political) culture of daily life. Furthermore, the hush that had fallen on families regarding political matters since the aftermath of the Civil War of 1918 has gradually given way to openness and curiosity; indeed, the silence was gradually broken thanks to the opening up of war archives and increased public discussion. After decades of silence, not only have the traces of politics in family histories emerged with greater clarity, but also those who have now spoken out are able to discuss events and experiences in relation to the present moment; namely, the moment of reflection and recollection. 
The writers who responded to the Politics and Power Games collection campaign defined their own relationship to the female perspective also by considering how well gender equality had been realised in Finland so far. The respondents considered the female agents who had operated on the grassroots level as embodiments of socially active womanhood. The written recollections also underscored the importance of historical female figures from the home region (e.g., writers who had had taken stands on social and political matters). In women's texts, the collective level tends to have more links to women's suffrage and social activism.

\section{WHO DETERMINES THE VALUE OF THE PAST?}

The authorised heritage discourse (hereinafter: AHD) legitimises what heritage or the past is, as discussed by Laurajane Smith (2006). The memorising aspects of political culture unpack the national political narrative of gender equality as an AHD (see also Heimo 2014 on digital memories). As unofficial heritage, political narratives thus perform political gender identities by revealing negative, dissonant political culture(s), as well as methods of survival in instances of sexual and political discrimination. By sharing their experiences, the respondents to the archive collection campaign illustrate the gap between micro and macro political narratives of equality (see Andrews 2012) and allow readers to understand how also difficult past experiences are given significance in the present (Smith 2008: 166; Harrison 2013; Logan \& Reeves 2009; Smith \& Akagawa 2009; Meskell 2002; Macdonald 2006; 2009; 2013).

Smith argues that one of the consequences of the AHD is that it defines who has the ability to speak for and about the nature and meaning of heritage (or 'the past', which is often used as an alternative to 'heritage'). On the one hand, as a memory institution, the Folklore Archives of the Finnish Literature Society represents an AHD insofar as it establishes the criteria for the kind of heritage deemed valuable, the renderings of the past most relevant for the future, or the kind of heritage most deserving of preservation. While it is true that the Folklore Archives also has its own regular writers' network, a group of people who act as 'spokespersons for the past', the collection campaigns are open to all who are interested in writing down their contribution (cf. Smith 2006: 29). On the other hand, respondents are authoritative narrators, as regards their own local and family histories, for they have the freedom to select the elements that are most important to them. The act of writing gives them greater authority over their stories on heritage discourses in their creation of personal narratives and meanings of the past. 
The stories function as a means of working through the past, reflecting an unofficial heritage from below (cf. Robertson 2012) and working as the 'empowerment narrative' for the contributors, especially when dealing with traumatic experiences (see Andrews 2007).

It is obvious that some find standard historical writings unproblematic, but for many it is actually a marginal representation of the past. The cultural heritage of children has recently been examined by researchers of memory/heritage studies and oral history; for example, the commemoration of child survivors of the Holocaust (see, e.g., Darian-Smith \& Pascoe 2012) or in Finland children's recollections of the return to peace after the Second World War (Korkiakangas 2009; in film see Kuusisto-Arponen 2011). My research material shows that in Finland, children and especially girls tend to pay attention to the local political atmosphere. Children participated in political activities either intentionally or unintentionally, both at home and during leisure time activities. When people recollect their wartime childhood, there is often a thin line between the concepts of experienced history and experienced politics as well as history narration and political narratives, because the narrators may see no difference between them. Silvia Salvatici (2008: 265), who has conducted an interview project in Kosovo in cooperation with the Archives of Memory, stresses that the interpretation of testimonials from a gender perspective has made a significant contribution to documenting multiple individual stories and war memories as part of and beyond nationalistic public discourse. In addition to war memories, reflecting invisible gendered reality and its narrativisation heritage from below should be taken into consideration more actively in oral history and heritage research on an international level.

In my research data, for instance, elections emerged as an interesting narrative theme concerning gendered reality. The stories that women told about elections not only generated a wealth of interpretations about gender and political culture; they also served to empower the women who did the telling. Below I examine how voting experiences create a dissonant heritage from below.

\section{RECOLLECTIONS OF VOTING AND ELECTIONS}

In the light of political history, it is understandable that voters' reminiscences of elections - starting with the early practice of voting, 'drawing a line' in 1907, and including more recent elections - make up one of the concrete themes in the Politics and Power Games collection campaign. Drawing a line refers to the practice of submitting a vote in Finnish parliamentary elections from 1907 to 1935. The expression is also familiar from Finnish literature (Kianto 1909) and 
film (1959). ${ }^{9}$ Nonetheless, reminiscences did not merely applaud Finnish women for their political independence; the texts also served as a reminder that gender equality had been achieved as a legal principle, but not always in everyday practice. Recollections of voting and elections are concretised by descriptions of the voting atmosphere, tensions between family members, unjust situations, etc. Though pressured by their husbands and male relatives, women had the fortitude to stand up for themselves. Yet, there is more to these memories than those concerning women gaining the right to vote. The year 1929, for example, marked the passing of the marriage act, a law which made both spouses equal before the law. This historical moment also coloured the recollections about women vis-à-vis politics. Nonetheless, even long after the law had come into force, many husbands continued to rule over their wives and families just as they had done before. In fact, some men even sought to control the hobbies and leisure activities of family members and relatives to uphold a certain political reputation. The following passage describes the experiences of a woman born in 1938. Her memories are situated in the agrarian culture of the 1970s. As we can observe, recollections bring up the contentious issues concerning both gender and political divisions:

My husband's brother gave me a talking-to on many an evening. He told me who to vote for. As the children grew up, he even expected us to choose their sports clubs according to the party. My husband's buddies made fun of the people whose children they considered to be on the wrong side; considerations of distance or schedules didn't make a difference. My husband was extremely timid under this pressure, but I kept my head for the children's sake: our children's hobbies are not to be determined by a political party or active local men. The boys can decide for themselves. They can go where their best friends go. I think many youngsters gave up athletics because of this... (SKS: KRA POL 1037. 2006)

The previous narrator made a stand against the political domination of the male community by placing her children outside of the day-to-day dictates of politics. The text reveals that men did not seek to link up their children's hobbies with any given political organisation for the sake of their political socialisation, but instead they selected their children's hobbies in order to maintain an image of the family's political position and reputation in the eyes of the male community. The memories are tinged with masculine power, a force that victimised not only the wives but also the husbands who feared the ridicule of their friends.

As we observed above with the case of being aligned with the 'wrong party', the writer, looking back to the 1960s and 1970s, puts a divided Finland under scrutiny. The division does not refer to a gender divide but rather to the political 
polarisation caused by the aftermath of the Civil War, which took place over ten years after universal suffrage had already been granted. The polarisation of the society was concretised in day-to-day life for those on both sides of the war, through the organisations, companies and clubs headed by the Leftist Reds and the Rightist Whites. Evidence of the societal split was present on a day-to-day level, as people did their shopping and banking, or even in their leisure time, when practising sports or enjoying other kinds of hobbies. As recently as this year, the Finnish media asked the country's citizens how the Civil War had affected their families (see also Heimo 2014). The question quickly spurred a lively discussion on the Internet: while some presented evidence of how traces of the political past continued to haunt even the younger generations, others dismissed history's influence on the present generations. ${ }^{10}$ This discussion underscores the results of a study on historical awareness by Pilvi Torsti (2012). The author suggests that there is no shared idea of a cornerstone of historical knowledge. The same can also be said about political history.

In the oral history texts, both men and women wrote down stories of men restricting and defining women's political rights. In this respect, these recollections undermine the myth of the politically independent Finnish woman. My research material shows that women were not always free to decide upon which candidate or party to vote for in elections, because their husbands and the latter's relatives dictated their decisions. This explains the abundance of memories concerning the role of mothers in supporting their daughters' political participation by encouraging them to vote and keep their own political mind, even if married.

Public shame serves as one explanation for the political quarrels within families in the small parishes: everybody looked forward to a certain election result because of the idea that each household unit should have been politically united. Locals knew exactly how farmers, merchants, workers, etc., voted; in other words, political supporters could easily be identified in a minor residential area, especially in politically homogeneous neighbourhoods. For example, if, during elections, a country parish known to have a majority of Agrarian Party supporters and only a few for the communists suddenly showed a radical growth in support of the Communist Party, the men began to suspect that their wives had gone ahead and voted for the wrong party. Although the next examples are typical narratives, atypical cases also feature in the context of the Finnish material, which, depending on the reader's background and experiences, might seem rather incomprehensible. The parents' political views are in opposition to each other in the first paragraph: the father's political stance, an active supporter of the Agrarian Party, stands in contrast to that of the mother, who appears to be politically wishy-washy and uninformed. By simultaneously 
supporting the co-operative shop and communistic E-movement and -shop, ${ }^{11}$ she is clearly out of step with the local political culture.

By then father had become an ardent supporter of the Agrarian Party. He also brought mother along to vote, even though she did not really have an opinion on politics. Mother knew so little about politics that she was a member of both the E-movement and the co-operative shop, a combination which back then was almost unheard of. [---] In the 1970s, political colours mattered and family members and relatives sometimes monitored the political views of their kin in a ludicrous manner. As a voter, I too have experienced moderate political pressure, which I nonetheless chose to ignore. (SKS: KRA. POL 1608. 2007)

Through her text, this female narrator (born in 1949) produces a gendered depiction of political culture by narrating the development of women's political independence. Her mother represents the previous female generation, the women who were deferred to their husbands and more or less lacked political independence and power in their marriages and among their family members. This image reflects the unspoken cultural model of gender inequality in some families; the narrator downplays her own subordinate position by not identifying those who tried to control her voting.

The passage below is one of the many writings in which a female narrator describes her experiences of gender-based political harassment. Writing under the pseudonym I'm not bitter, but ..., a woman who was born in 1937 writes about the extreme political pressure and control in her marriage:

As a young adult, I did not vote in elections. But after I got married, my husband made me vote for his favourite candidate. It was only after 30 years of marriage that I had the right to vote for a female candidate, as long as she represented the right party. So, my husband had two votes, and I had none. At the beginning of this century, after 40 years of marriage, he died, and that is why I now have the freedom to vote for whichever party I want. (SKS: KRA. POL 1602-1603. 2007)

The woman confesses to having a passive attitude towards elections before she got married. After marriage, however, her opinion of her right to political self-determination changes suddenly. Her husband's domination of her choice of candidate made her feel as though she did not even have the right to vote. Without a doubt, her role as a wife imprisoned her politically, and it took decades and his death for her to gain her political freedom. As an avid supporter of a certain party, the husband had suspected that his wife might not share the same loyalties. The example shows that, for one reason or another, the wife 
simply did as she was told. The writer does not try to explain why her husband felt that he had the right to control her during the elections. Interestingly, however, the writer implies that she never gave up: after 30 years of marriage she was finally given permission to vote for a female candidate, as long as she represented the right party. Yet, it was not until her husband's death that she could freely vote for whomever she wished. Her personal experiences tarnish the image of the celebrated history of Finnish suffrage.

\section{TENSION, POWER, AND POLITICAL POSITIONS}

Like biographical interviews, written memoirs also grant us a privileged perspective on personal experiences: how the gender system is experienced from within, a system whereby a woman's activities and place in society is organised according to the framework of family life (Patai \& Gluck 1991; see also Armitage 2011; Ashton \& Kean 2012). The narratives that reflect politics in families

convey knowledge about the tensions created among family members due to politics; they are narratives about power, resistance, and women's efforts to break free from their subordinated political positions due to gender. The next somewhat extreme example goes beyond mental domination to physical control, but here, too, party politics is at issue. The narrator was born in a small village near the Russian border, in the Kainuu region of Finland, in 1939:

During the Second World War, two brothers moved to our home region. Both of them married local girls and had a lot of children. After the war, the brothers were given farms to live on and lots of forestland from the state, which they were proud of. One of them was a candidate for the Communist Party in the municipal elections. The wife of the other brother said that she would not vote for him. On election day the husband tied his wife to a table leg to stop her from voting. (SKS: KRA POL 2111-2118. 2007)

What kinds of interpretations can we arrive at from this memory text? How does this particular narrativised memory come across, for instance, to a young woman raised on the master narrative of suffrage about Finnish women, the first in the world to exercise their right to vote? Once again this may say "less about the events than about their meaning", as Alessandro Portelli (2006: 55; originally 1979 in Italian) has phrased it in his classic writings. In contrast to the previous examples, this passage emerges as part of a local narrative instead of a personal or family narrative. It can be read and interpreted in many ways: as a narrative representing the extreme politics of the time, as a story of domestic violence, or one simply reiterated for its comical tone. 
The materials kept in the Folklore Archives contain countless examples of women's conscious political resistance to male-dominated political power. Hardly nostalgic, these stories do not paint an idyllic picture of family life. Yet, these stories are fundamental to women's political empowerment. They transmit models of political independence extending over generations. One perspective on them is evident in the following passage, in which a woman born in 1937 reveals her strategy:

I suppose my marriage resembled that of my parents when it came to voting. My husband only thought he knew who I voted for. Though I wouldn't say that I lied to him, and nor did Mom back then. We didn't have to because the men were so sure about our solidarity with them: they didn't even ask us for our opinions! (SKS: KRA. POL 1094-1111. 2007)

The brief passage above juxtaposes the men's image of themselves as leaders of the family in political allegiance and thought with the reality of their wives' quiet dissent. The men's firm belief in their wives' political solidarity meant that such choices were not even a matter of discussion. Somewhat ironically, this allowed both the mother and daughter to cultivate, albeit secretly, their own independent political stance.

Although women are the main protagonists in these narratives, memories of political culture are not confined to merely women's experiences of political pressure. Men, too, had met with political violence, but not at home, for incidents of such political pressure mainly occurred in work communities during the $1960 \mathrm{~s}$ and 1970s. Political bullying and threatening happened, for example, in the army, where the parish registers were inspected for the family backgrounds of soldiers from the post-war generations. Some respondents said that these issues continue to be hushed up in Finland (SKS: KRA. POL 2009-2013: 960-971, 1212-1217, 1285-1290, 1567-1570. 2006-2007). In addition, men themselves also criticise their own enduring tendencies to keep women on the margins of political power. Born in Karelia in 1932, the man cited below states that "previously no men agreed to vote for a female candidate". He specifies that female candidates were generally more tolerated in the municipal than in the parliamentary elections. He thinks that these attitudes derived from the rural masculine mentality: In the countryside women were not accepted; they said, 'no hags in politics'! (SKS: KRA. POL 1365. 2006) In this case, the respondent is not referring to his own opinions, but to the rural male perspective. In fact, through the stories he tells, he affirms the model for the politically active and independent woman. At the beginning of the 1900s, when women's suffrage became a reality in Finland, his grandmother knew how to read but could not 
write. However, as he describes it, she felt that women had a reason to celebrate their full political rights:

Oral history is full of narratives about Finnish women's suffrage in 1906; so my father's mother Anna Sofia said to other women: 'Now we must dress up nicely, put on our Sunday skirts and go to vote!' Women in the countryside didn't feel it was important to vote since not even all the men voted, especially in the municipal elections. Men did give their votes in the parliamentary elections, although the political party programmes were not easy to follow, making it difficult for the illiterate women in the countryside to understand. It is said that the socialists collected grain from those who voted for them, but the farmers got angry about it, changed their political views and joined the Agrarian Party instead. (SKS: KRA. POL 1363. 2006)

This example shows us how a short passage of narration incorporates different elements of knowledge. The mention of dressing up marks the consciousness of a movement from everyday frames to an exceptional event, signalling that something extraordinary was in hand. The protagonist uses the Sunday skirt as a symbol of collective power, but her political enthusiasm fails to catch on when rural reality clashes with political ideals. The interests of the illiterate country women and the protagonist are clearly at odds. The passivity of the illiterate women can be interpreted as a questioned obligation as opposed to a failure to appreciate their newly given right to vote. If the men were reluctant to vote, why would the women even bother? Moreover, the paragraph reflects the way that different elections were ranked: the municipal elections failed to get the same attention from voters as the parliamentary elections. At this point in the narrative, the narrator underlines the incompetence of the illiterate women, whose inability to read is connected to ignorance, which serves to explain their listless voting behaviour. In the end, the memoirs include a more general description about the socialists' unjust method of collecting grain and trying to buy votes by doing so - a practice that ultimately backfired. At the local level, politics appeared to be a game, a novelty that the rural people failed to understand.

Political narratives that touch upon elections and voting show that women feel compelled to demand their political rights and raise their daughters to be politically independent. Women's writings clearly reveal their grasp of the potential to make a difference as a woman: many female respondents described how they had sought to find a woman from among the candidates, because their mothers had always underlined the importance of women exercising their right to vote. 


\section{CONCLUSION}

So far, there is no archive dedicated solely to women's history in Finland. Nonetheless, the respondents to the Politics and Power Games collection campaign contributed to the presentation of the political culture of the past by writing about their everyday gendered experiences. The main purpose of political narratives is to pass down multi-dimensional historical and political knowledge through experienced history, including political and local pasts, and thus serve as a counter-history. Therefore political narratives make up a part of the process of changing past images; these narratives constitute a part of re-naming and transmitting the collective memory to challenge the significance of the master narrative or the AHD about politically equal Finnish women. I sought to find out what kinds of gendered political past(s) and forms of vernacular political culture(s) people have wanted to record and why, in the context of the history collection campaign of the Folklore Archives of the Finnish Literature Society.

Producing a personal, gender-based narrative of Finnish political culture by writing to a collection campaign is a process whereby writers can evaluate their memories of the multifaceted political atmosphere of their childhood environment. Contributing to political history through one's own memories proves that, both as a category and a concept, politics and history are not at a remove from individuals' personal spheres and life cycles.

The political narratives as textual items can be regarded as cultural heritage (cf. documentary heritage in: Edmonson 2002; Olsson forthcoming). Paula Hamilton and Linda Shopes (2008: 3) make the following statement in Oral History and Public Memory:

Oral history has informed the creation of cultural heritage understood broadly as a socially sanctioned, institutionally supported process of producing memories that make certain versions of the past public and render other versions invisible.

Here the importance of different versions of the past should be noted. Gender has been overlooked in discussions of 'heritage', because an authorised heritage discourse acts to constitute the way we think, talk and write about the past and heritage. These hegemonic discourses are reliant on (masculine) power and memory, which ultimately serve to naturalise the grand narratives of the nation. This means that patriarchal culture becomes the heritage of all members of society (Smith 2006: 11; 2008: 162).

It is true that so far the field of heritage studies has produced only a negligible number of studies that integrate gender perspectives - or, we are often 
led to assume that men have no gender (see Smith 2008: 159). It is therefore reasonable to ask how our gendered visions of the past and political narratives are constructed and stored. In spite of the fact that no comparative material is used in my research, I believe that there are narratives of women's politically coloured (childhood) experiences inside many life historical collections, along with memories of trauma, political prisoners, war experiences, ideology, etc. (see especially Kirss \& Kõresaar \& Lauristin 2004).

Even though my research materials supported and perpetuated the narrative about women's political rights and the myth of the strong political woman, the recollections challenged the narrative of women's active participation in politics. Narrated personal experiences of women and men transmitted within the family showed that negative attitudes towards women's political freedom persisted, especially in the countryside. It is noteworthy that not only women but also men had experienced political pressure and suffered for their political opinions. Although men may have ruled over their wives in the home, some faced political discrimination at the workplace or during their leisure time.

In order to understand the processes underlying women's political socialisation, we need to see how women in their recollections describe and situate their political awakenings and where they have found the strength to overcome political pressure. In recent years, Finnish researchers have actively focused on the impact of nonfiction on the reading public during the early 20th century, a period when the genre - especially autobiographical writing - aided in the creation of a national consciousness (see Jalava \& Kinnunen \& Sulkunen 2013). My research data has shown that politically or culturally active role models relatives, local writers, female politicians, novelists or advocates of women's suffrage - have often served as an impetus for women's political awakening. In my research materials, the significance of traditional civic organisations (e.g., the Marthas and Lottas) that represent better family life or patriotic values are also often mentioned. My research thus demonstrates that the creators of written recollections - especially women but occasionally also men - felt that the archive collection campaign offered them an opportunity to tell not only researchers but also future generations about their life experiences and unseen gendered perspectives on politics, both of which have generally been overlooked in accounts of political history. The writers also offered an insight into how children experience political culture as observers and how political legends can aid in dealing with the community's necessary, real and potential political conflicts. 


\section{ACKNOWLEDGEMENTS}

The language editing of this article was done by Leila Virtanen and funded by the Cultural Meanings and Vernacular Genres (CMVG) -research community based at the University of Helsinki (led by Docent Pertti Anttonen). The author would also like to thank the reviewers and editors Anne Heimo and Ene Kõresaar for their insightful comments.

\section{NOTES}

1 This article is based on a chapter on politics and gender from my monograph published in Finnish Kerrottu politiikka (Narrated Politics) in 2013 (Latvala 2013b). The sentence in the title is taken from my research materials (the Politics and Power Games collection) stored in the Folklore Archives at the Finnish Literature Society in Helsinki.

2 While British archivists have primarily conducted oral history interviews within their own communities through mass-observation (see Sheridan \& Street \& Bloome 2000), their counterparts in Finland, as well as archivists in Sweden, Norway and Estonia, have organised written collection campaigns (see Bohman 1986; a corresponding term in Estonia is 'oral popular history' ('pärimuslik ajalugu'), see Hinrikus \& Kõresaar 2004).

3 These collections bring forth multiple historical actors and various perspectives on the past, enlarging our understanding of recent history and its social processes. As Kõresaar \& Kuutma \& Lauk (2009: 17-19) have pointed out, the biographical approach has furthered discussions of gender, individual everyday meanings, positionality and emotions in representations of the past. (See also Summerfield 1998: 2, 9-11, 28; Kõresaar \& Kuutma \& Lauk 2009: 18; Latvala \& Laurén 2013.)

4 For more information (in English) on the Politics and Power Games collection campaign, see the following website: http://www.helsinki.fi/sukupuolentutkimus/aanioikeus/en/ index.htm. For information in Finnish, see: http://www.finlit.fi/kra/keruut/politiikka. htm. The co-organisers were (in Finnish): Yhteiskuntatieteellinen tietoarkisto FSD, Naisjärjestöt yhteistyössä (NYTKIS) ry, Maaseudun Sivistysliitto, Sisäasiainministeriön maaseudun naisteemaryhmä and Suomi 90 Finland. I have not concentrated on entire life histories or extensive units of text as such in this article, but have chosen to highlight the examples that display the theme of gender and politics. In my book I have carefully investigated nine case studies.

5 See also Latvala 2013a.

6 In addition to the actual oral history collections stored in archives, the voices of women's heritage are channelled, among others, into informal archives of intangible, digital heritage, as Sheenagh Pietrobruno (2013) demonstrates in her research on YouTube as an archive. Integrating social media and archive studies with actual and 
virtual ethnography, Pietrobruno examines UNESCO and user-generated heritage videos of Turkish whirling dervish ceremonies. She reveals that social archiving can capture intangible heritage as an ongoing process and therefore has the potential to problematise and counter official heritage narratives, which are somewhat static and often make hierarchical gender distinctions visible. Pietrobruno underlines that female dervishes have been excluded from the national heritage, but YouTube has aided in safeguarding their heritage (ibid.: 2).

7 Alongside UNESCO's Memory of the World Programme international register, the focus on archives and preserving documentary heritage has been discussed worldwide. It 'reflects the diversity of languages, peoples and cultures. It is the mirror of the world and its memory.' UNESCO's Memory of the World: Guidelines to Safeguarding Documentary Heritage (2002) defines also oral history recordings as a specific area of heritage.

8 The author would like to thank Docent Pia Olsson for her valuable comments and information concerning the collection projects in the National Archives (e-mail 25.11.2013).

9 A historical novel by Ilmari Kianto (1909): Punainen viiva (The Red Line). The film adaption was directed by Matti Kassila in 1959.

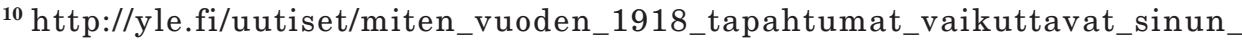
suvussasi/6608009.

${ }^{11}$ In the countryside, the E-movement, a progressive co-operative movement that started in 1964, primarily served the interests of petty bourgeois shopkeepers, but in the cities the movement was more extensive and involved working class people.

\section{ARCHIVAL MATERIALS}

The Finnish Literature Society Folklore Archives, Politics and Power Games collection. Helsinki, Finland.

\section{ABBREVIATIONS}

SKS - Suomalaisen Kirjallisuuden Seura (Finnish Literature Society)

KRA - Kansanrunousarkisto (Folklore Archives)

POL - Politiikkaa ja valtapeliä -keruu (Politics and Power Games -collection) 


\section{REFERENCES}

Andrews, Molly 2007. Shaping History: Narratives of Political Change. Cambridge: Cambridge University Press.

Andrews, Molly 2012. What is Narrative? Connecting Micro and Macro Political Stories. Available at http://www.novella.ac.uk/documents/Connecting_Micro_and_Macro_ Political_Stories.pdf, last accessed on February 13, 2014.

Armitage, Sue 2011. The Stages of Woman's Oral History. In: D. A. Ritchie (ed.) The Oxford Handbook of Oral History. Oxford: Oxford University Press, pp. 169-185.

Ashton, Paul \& Kean, Hilda (eds.) 2012. People and their Pasts: Public History Today. New York: Palgrave Macmillan.

Bendix, Regina. 2009. Heritage between Economy and Politics: An Assessment from the Perspective of Cultural Anthropology. In: L. Smith \& N. Akagawa (eds.) Intangible Heritage. London \& New York: Routledge, pp. 253-269.

Benton, Tim \& Cecil, Clementine 2010. Heritage and Public Memory. In: T. Benton (ed.) Understanding Heritage and Memory. Manchester \& New York: Manchester University Press, pp. 7-43.

Bohman, Stefan 1986. The People's Story: On the Collection and Analysis of Autobiographical Materials. Methodological Questions, No. 3. Stockholm: Stockholm Nordiska Museet, pp. 3-23.

Darian-Smith, Kate \& Pascoe, Carla (eds.) 2012. Children, Childhood and Cultural Heritage. London and New York: Routledge.

Edmonson, Ray 2002. Memory of the World: General Guidelines to Safeguarding Documentary Heritage. Paris: UNESCO. Available at http://unesdoc.unesco.org/ images/0012/001256/125637e.pdf, last accessed on February 13, 2014.

Grele, Ronald J. 2007. Reflections on the Practice of Oral History: Retrieving What We Can from an Earlier Critique. Special Issue: Memory and Narration: Oral History Research in the Northern European Context. Suomen Antropologi, Vol. 32, No. 4, pp. 11-23. Helsinki: The Finnish Anthropological Society.

Hamilton, Paula \& Shopes, Linda (eds.) 2008. Introduction: Creating Heritage. In: Oral History and Public Memories. Philadelphia: Temple University Press, pp. 3-6.

Harrison, Rodney 2013. Heritage: Critical Approaches. London \& New York: Routledge. Heimo, Anne 2010. Kapina Sammatissa. Vuoden 1918 paikalliset tulkinnat osana historian yhteiskunnallisen rakentamisen prosessia. [Rebellion in Sammatti. Local Interpretations of the 1918 Finnish Civil War as Part of the Social Process of History Making.] Helsinki: Suomalaisen Kirjallisuuden Seura.

Heimo, Anne 2014. The 1918 Finnish Civil War Revisited: The Digital Aftermath. Folklore: Electronic Journal of Folklore, Vol. 57, pp. 141-168. doi: 10.7592/ FEJF2014.57.heimo.

Hinrikus, Rutt \& Kõresaar, Ene 2004. A Brief Overview of Life History Collection and Research in Estonia. In: T. Kirss \& E. Kõresaar \& M. Lauristin (eds.) She Who Remembers Survives: Interpreting Estonian Women's Post-Soviet Life Stories. Tartu: Tartu University Press, pp. 19-34. 
Howard, Robert Glenn 2013. Vernacular Authority: Critically Engaging ‘Tradition'. In: T. J. Blank \& R. G. Howard (eds.) Tradition in the Twenty-First Century: Locating the Role of the Past in the Present. Logan: Utah State University Press, pp. 72-99.

Jalava, Marja \& Kinnunen, Tiina \& Sulkunen, Irma (eds.) 2013. Kansallinen historiakulttuuri - näkökulmia yksiäänisyyden purkamiseen. [The National History Culture: Perspectives on Dismantling Singlevoicedness.] In: M. Jalava \& T. Kinnunen \& I. Sulkunen (eds.) Kirjoitettu kansakunta: sukupuoli, uskonto ja kansallinen historia 1900-luvun alkupuolen suomalaisessa tietokirjallisuudessa. [The Written Nation: Gender, Religion, and National History in Finnish Nonfiction in the First Half of the 20th Century.] Helsinki: Suomalaisen Kirjallisuuden Seura, pp. 7-27.

Kalela, Jorma 2012. Making History: The Historian and the Uses of the Past. Basingstoke: Palgrave Macmillan.

Kalela, Jorma 2013. Making History. The Historian and Uses of the Past. In: H. Kean \& P. Martin (eds.) The Public History Reader. London and New York: Routledge, pp. 104-128.

Kianto, Ilmari 1909. Punainen viiva. [The Red Line.] Helsinki: Otava.

Kirss, Tiina \& Kõresaar, Ene \& Lauristin, Marju 2004. She Who Remembers Survives: Interpreting Estonian Women's Post-Soviet Life Stories. Tartu: Tartu University Press.

Kõresaar, Ene \& Kuutma, Kristin \& Lauk, Epp 2009. The Twentieth Century as a Realm of Memory. In: E. Kõresaar \& K. Kuutma \& E. Lauk (eds.) The Burden of Remembering. Recollections \& Representations of the 20th Century. Helsinki: Suomalaisen Kirjallisuuden Seura, pp. 9-34.

Korkiakangas, Pirjo 2009. The War that Continued after the Peace. Memories of the Return to Peace, Recollected by Elderly Finns Sixty Years after the End of World War II. In: E. Kõresaar \& K. Kuutma \& E. Lauk (eds.) The Burden of Remembering. Recollections \& Representations of the 20th Century. Helsinki: Suomalaisen Kirjallisuuden Seura, pp. 57-75.

Kuusipalo, Jaana 2011. Sukupuolittunut poliittinen edustus Suomessa. [Gendered Political Representation in Finland.] Acta Universitatis Tamperensis 1614. Tampere: Tampere University Press.

Kuusisto-Arponen, Anna-Kaisa 2011. The Politics of Identity and Visuality: The Case of Finnish War Children. In: M. Stocchetti \& K. Kukkonen (eds.) Images in Use: Towards the Critical Analysis of Visual Communication. Discourse Approaches to Politics, Society and Culture, Vol. 44, pp. 181-198.

Latvala, Pauliina 2005. Katse menneisyyteen. Folkloristinen tutkimus suvun muistitiedosta. [A Glimpse into the Past: A Folkloristic Investigation into Oral History of the Family.] Helsinki: Suomalaisen Kirjallisuuden Seura.

Latvala, Pauliina 2013a. The Narrativization of Political Socialization in Finnish Oral History Texts. Journal of Finnish Studies, Vol. 16, No. 2, pp. 141-159.

Latvala, Pauliina 2013b. Kerrottu politiikka. Muistitietotutkimus arjen poliittisesta kulttuurista. [Narrated Politics. Oral History on Everyday Political Culture.] Helsinki: Suomalaisen Kirjallisuuden Seura. 
Latvala, Pauliina \& Laurén, Kirsi 2013. The Sensitive Interpretation of Emotions: Methodological Perspectives on Studying Meanings in Written Life-Historical Narratives. In: Frog \& P. Latvala with Helen F. Leslie (eds.) Approaching Methodology. Helsinki: Academiae Scientiarum Fennicae, pp. 249-266.

Liljeström, Marianne 2004a. Useful Selves: Russian Women's Autobiographical Texts from the Postwar Period. Helsinki: Kikimora Publications.

Liljeström, Marianne 2004b. Kokemukset ja kontekstit historiankirjoituksessa. [Experiences and Contexts in History-Writing.] In: M. Liljeström (ed.) Feministinen tietäminen: Keskustelua metodologiasta. Tampere: Vastapaino, pp. 141-166.

Logan, William \& Reeves, Keir 2009. Introduction: Remembering Places of Pain and Shame. In: W. Logan \& K. Reeves (eds.) Places of Pain and Shame: Dealing with 'Difficult Heritage'. Key issues in Cultural Heritage. London and New York: Routledge, pp. 1-14.

Lowenthal, David 1985. The Past is a Foreign Country. Cambridge: Cambridge University Press.

Macdonald, Sharon 2006. Undesirable Heritage: Fascist Material Culture and Historical Consciousness in Nuremberg. International Journal of Heritage Studies, Vol. 12, No. 1, pp. 9-28. http://dx.doi.org/10.1080/13527250500384464.

Macdonald, Sharon 2009. Difficult Heritage. London and New York: Routledge.

Macdonald, Sharon 2013. Memorylands: Heritage and Identity in Europe Today. London \& New York: Routledge.

Markkola, Pirjo 2002. Vahva nainen ja kansallinen historia. [Strong Woman and National History.] In: T. Gordon \& K. Komulainen \& K. Lempiäinen (eds.) Suomineitonen hei! Kansallisuuden sukupuoli. Tampere: Vastapaino, pp. 75-90.

Meskell, Lynn 2002. Negative Heritage and Past Mastering in Archaeology. Anthropological Quarterly, Vol. 75, No. 3, pp. 557-574. http://dx.doi.org/10.1353/anq.2002.0050.

Miettunen, Katja-Maria 2009. Menneisyys ja historiakuva: Suomalainen kuusikymmentäluku muistelijoiden rakentamana ajanjaksona. [The Past and the Image of the Past: The Finnish Sixties as an Epoch Constructed by Reminiscences.] Helsinki: Suomalaisen Kirjallisuuden Seura.

Olsson, Pia 2011. Women in Distress: Self-Understanding among 20th-Century Finnish Rural Women. Zürich: LIT Verlag.

Olsson, Pia forthcoming. Questionnaires Eliciting 'Good Factual Knowledge': Traditions from Below - or Above? Journal of Finnish Studies.

Patai, Daphne \& Gluck, Sherna Berger 1991. Women's Words: The Feminist Practice of Oral History. London \& New York: Routledge.

Peltonen, Ulla-Maija 1996: Punakapinan muistot. Tutkimus työväen muistelukerronnan muotoutumisesta vuoden 1918 jälkeen. [Memories of the Civil War: A Study of the Formation of the Finnish Working-Class Narrative Tradition after 1918.] Helsinki: Suomalaisen Kirjallisuuden Seura.

Pietrobruno, Sheenagh 2013. YouTube and the Social Archiving of Intangible Heritage. New Media and Society, Vol. 15, No. 8, pp. 1259-1276. doi: 10.1177/1461444812469598.

Portelli, Alessandro 2006. Mikä tekee muistitietotutkimuksesta erityisen? [What Makes Oral History Special?] In: O. Fingerroos \& R. Haanpää \& A. Heimo \& U.-M. 
Peltonen (eds.) Muistitietotutkimus. Metodologisia kysymyksiä. [Oral History Research: Methodological Issues.] Helsinki: Suomalaisen Kirjallisuuden Seura, pp. 49-64. [Original in Italian in 1979. Sulla specificita della storia orale. Primo Maggio.]

Robertson, Iain J.M. (ed.) 2012. Heritage from Below. Ashgate Publishing Limited.

Salvatici, Silvia 2008. Public Memory, Gender, and National Identity in Postwar Kosovo: The Albanian Community. In: P. Hamilton \& L. Shopes (eds.) Oral History and Public Memories. Philadephia: Temple University Press, pp. 253-267.

Schudson, Michael 1995. Dynamics of Distortion in Collective Memory. In: D.L. Schachter \& J.Y. Coyle (eds.) Memory Distortion: How Minds, Brains and Societies Reconstruct the Past. Cambridge MA: Harvard University Press, pp. 346-364.

Sheridan, Dorothy \& Street, Brian \& Bloome, David 2000. Writing Ourselves: MassObservation and Literacy Practices. New Jersey: Hampton Press Inc.

Smith, Laurajane 2006. Uses of Heritage. London and New York: Routledge.

Smith, Laurajane 2008. Heritage, Gender and Identity. In: B. Graham \& P. Howard (eds.) The Ashgate Research Companion to Heritage and Identity. London: Ashgate, pp. 159-180.

Smith, Laurajane \& Akagawa, Natsuko (eds.) 2009. Intangible Heritage. London and New York: Routledge.

Smith, Laurajane \& Waterton, Emma 2009. 'The Envy of the World?': Intangible Heritage in England. In: L. Smith \& N. Akagawa (eds.) Intangible Heritage. London and New York: Routledge, pp. 289-302.

Sulkunen, Irma 1991. Retki naishistoriaan. [Excursion to Women's History.] Helsinki: Hanki ja jää.

Sulkunen, Irma \& Markkola, Pirjo 2009. Introduction. In: I. Sulkunen \& S.-L. NevalaNurmi \& P. Markkola (eds.) Suffrage, Gender and Citizenship: International Perspectives on Parliamentary Reforms. Newcastle upon Tyne: Cambridge Scholars Publishing, pp. 1-11.

Summerfield, Penny 1998. Reconstructing Women's Wartime Lives. Manchester: Manchester University Press.

Torsti, Pilvi 2012. Suomalaiset ja historia. [The Finns and History.] Helsinki: Gaudeamus.

\section{WEBSITES}

http://yle.fi/uutiset/miten_vuoden_1918_tapahtumat_vaikuttavat_sinun_ suvussasi/6608009, last accessed on February 14, 2014.

http://www.finlit.fi/kra/keruut/politiikka.htm, last accessed on February 14, 2014.

http://www.unesco.org/new/en/communication-and-information/access-to-knowledge/ preservation-of-documentary-heritage/, last accessed on February 14, 2014. 
Pauliina Latvala

\section{E-MAILS}

Doc. Pia Olsson's e-mails to the author from 25.11.2013 and 13.01.2014, in author's possession. 